\title{
The influence of mentoring on teachers performance in reading instruction for dyslexia children
}

\author{
Irdamurni $^{1}$, Kasiyati ${ }^{2}$, Zulmiyetri ${ }^{3}$, Johandri Taufan ${ }^{3}$ \\ ${ }^{1}$ Faculty of Education, UniversitasNegeri Padang, Indonesia, هirdamurni241161@gmail.com \\ ${ }^{2}$ Faculty of Education, UniversitasNegeri Padang, Indonesia \\ ${ }^{3}$ Faculty of Education, UniversitasNegeri Padang, Indonesia \\ ${ }^{4}$ Faculty of Education, UniversitasNegeri Padang, Indonesia
}

\begin{abstract}
The article aims to identify the influence of mentoring on teachers' performance in conducting the class for dyslexia children in elementary school. The subjects of research were 18 teachers of class I to class VI at inclusive elementary school. The data collected using observation and interviews as well as document analysis of the teachers performance in the learning process for dyslexia children. The study includes identification and assessment, curriculum development at inclusive school; lesson plans ( RPP) modification and learning strategies in reading instruction for dyslexia children. This research used a descriptive qualitative approach. The results showed that the teachers' performance in reading instruction for dyslexia children has improved after mentoring on reading for dyslexia children was given.
\end{abstract}

Keywords:Mentoring, teachers performance learning, children with dyslexia.

This is an open access article distributed under the Creative Commons 4.0 Attribution License, which permits unrestricted use, distribution, and reproduction in any medium, provided the original work is properly cited. $\odot 2018$ by author and Faculty of education, UniversitasNegeri Padang.

\section{Introduction}

This paper is drawn from prior research by Irdamurni and Noviana in 2013, which found that the prevalence range of children with dyslexia in Pauh district, Padang is between 10 to $15 \%$, followed by the research conducted by Irdamurnietc in 2017 which found that Mingle technique is effective in improving the reading skills of dyslexia children both in lower and higher grades of elementary school. The findings were in line with Yusuf's research in 2003 (P. 69) that showed more than 10\% students face difficulty in reading and also Wood (1993) on his epidemiology research which found reading difficulty more than $90 \%$ of the overall non-psychiatric learning difficulty.

Vellutino, Fletcher, Snowling\& Scanlon (2004) stated that dyslexia occurs in $10 \%$ to $15 \%$ of the children population in school, means that one out of 10 children is suffering from dyslexia, thus there are at least 2.4 million children with dyslexia in Indonesia. Dyslexia is an error on the child's cognitive process when receiving information in reading. In addition, ShaywitzShaywitz (2003) argued that dyslexia is a specific learning difficulty derived from Neurobiology, which characterized in the accuracy or fluency to recognize words, inability to spell and encode words.

Reading skills for dyslexia children differ from the normal ones in which normal children have started to read since the age of six or seven years while children with dyslexia are sometimes still 
unable to read fluently even when they reach 12 . This difficulty can be detected when they attend elementary school (Irdamurni, 2017). The findings on the research conducted by Irdamurni (2018) showed the errors made by dyslexia children in reading are generally started from the concept of space, the concept of direction and place. Children who fail to understand the concept of space, the concept direction and the concept of time, have difficulty in distinguishing letters, and failure in connecting the vowels and consonants.

Reading is one of the pivotal academic components at the school. Reading is a tool for one to achieve his goals (Guthrie, Alao Rinehart, 1996). The complex reading behavior involves the ability to think, and every word in reading itself shows a variety of different activities (Beaton, 2004). Someone requires interactive capability when reading, which means the reader gives meaning on the readings based on his experience, hence the interaction is employed between the readers and the readings (Afangideh Jude, 2012).

The findings based on Irdamurni and Noviana in 2013 discovered that one of the factors which caused the high number of dyslexia children in Pauh district, Padang is the low level of competence and performance of elementary school teachers in teaching early reading in lower grades and advanced reading in higher grades. One of the methods to improve the teachers' performance and competence is by giving continual mentorship to the teachers who assist children with dyslexia.

Mentorship conducted in this research is a process of guidance provided by the lecturer to the teachers in the implementation of reading for children with dyslexia. Mentoring is one of the efforts to pave the way for someone to learn in order to develop his full potential. TrubusRaharjo (2017) stated that mentoring is a follow-up training that is used as a monitoring tool to determine the effectiveness of the training. Mentorship provides feedback on the training itself and influences the teachers' performance. The learning process will be implemented properly and thus the teachers' competence in teaching reading lesson for children with dyslexia will improve.

Performance is an outcome of a work that is qualitatively and quantityly achieved by an employee in carrying out his duties in accordance with the responsibilities given to him. Meanwhile, performance in learning is the ability or skills of a teacher in creating the communicative atmosphere between the teacher and the students in terms of the cognitive, affective and psychomotor. Given the importance of mentoring programs for the teachers, the schools require mentoring and monitoring which aim to find out whether the implementation of reading instruction for dyslexia children was properly conducted. If it was not conducted accordingly, the problems need to be identified and the mentorship should be provided to the teachers associated to solve the problems encountered in the practice. Through mentorship, the teachers are able to foster confidence, self-reflection, and selfawareness; that they are able and willing to make improvements continuously even without any supervisions.

The purpose of this research is to identify the elementary school teachers' performance in reading instruction for children with dyslexia. Mentoring is conducted to the teachers regarding the problems encountered in identification and assessment implementation, the development of Lesson Plan (RPP) modification and Individualized Education Program (PPI) and learning strategies in reading for dyslexia children. After the mentoring is implemented, the measurement is conducted by analyzing whether the mentoring has provided a significant influence on the teachers' performance in reading instruction for dyslexia children.

\section{Method}

The type of research is qualitative. The writer used qualitative approach by collecting the data directly to the teachers who assist children with dyslexia in the elementary school. The data interpreted and inferred were obtained from observation, interviews and document analysis. According to Moleong (2007), the main data source in qualitative research is words and actions. The 
analysis of data source in this research was the teachers who assist children with dyslexia at the elementary school in Padang. The subjects were taken from three inclusive elementary schools in Padang where the trial was conducted in prior research. The samples were children with dyslexia, in the stage of dissemination, mentoring was employed for the teachers who assist children with dyslexia.

\section{Results and Discussion}

Mentoring is operationally proven to improve the teachers' performance in reading instruction for dyslexia children. This is proven by the results of document analysis before and after given the mentorship. The improvements were seen from the teachers' document as the learning device for children with dyslexia; the format of identification and assessment for children with dyslexia. Some issues were found before the mentoring was conducted. The regular teachers did not apply identification and assessment for children with dyslexia, because the duty was managed by the special education teacher. In terms of curriculum development for children with dyslexia, the regular teachers did not modify the lesson plan (RPP) and Individualized Education Program (PPI). Individualized Education Program was only assigned to special education teacher which was also incomplete and inadequate for the students with dyslexia. Another issue was found in the learning process conducted in the classroom. The regular teachers applied the same way to teach the dyslexia children with others whereas they actually require a different way of teaching. The teachers also did not use the Lesson Plan (RPP) modification and Individualized Education Program (PPI). After the mentorship was given, the teachers' performance has improved. This proves that mentoring has contributed to a significant improvement in teachers' performance in elementary school after mentoring in reading instruction for children with dyslexia was provided.

The findings show that mentoring has improved the elementary school teachers' performance when teaching reading instruction for children with dyslexia. Based on observation, interviews and document analysis conducted by the researcher, the teachers receive progress in the learning process. The teachers did not feel patronized when the researcher help them to improve their ability in teaching children with dyslexia as the researcher only provided advice and suggestions as well as the example of each aspect. The example of the aspects includes the format of identification, the format and the results of the assessment for dyslexia children. As for the aspect of curriculum development, the researcher provided the example of Lesson Plan (RPP) modification and the example of the Individualized Education Program (PPI) to the teachers. However, in the learning process, the observation depended on the teachers' readiness to be observed.

This is in accordance with Suprijanto (2008) who argued that methods indicated for adult education are; formal presentation such as lectures, question and answer, discussions, symposia and audiovisual (watching a movie) where adults do not feel patronized.

The argument is also supported by Lunandi (1982) and Soedomo (1989) who stated the atmosphere of conducive learning for adults are as follows: (1) encourage the learners to actively develop their talents (2) the atmosphere of mutual respect and appreciation, (3) the atmosphere of mutual trust and openness, (4) self-discovery, (5) non-threatening atmosphere, (6) admits a personal distinctiveness, (7) allows diversity, errors, and doubt (8) allows adults to learn their interest, (9) allows adults to admit and examine personal, group and community's weaknesses and strengths (10) allow adults to grow in accordance with existing norms and values in society.

The terms above are applied in the training and supervision models using coach method that is developed in the model. This includes requesting the reflection from the participants when every learning material is presented, giving reinforcement to the participants who actively give opinions and feedback as well as questions in the learning process. 


\section{References}

Afangideh, M.E \& Jude, W.I. (2012). Developing Literacy Skill to Enhance Aca-demic Performance of Learners in UYO Education Zone. Academic Research International. Journal Social Sceince Humanities. Vol.3. No.3.

Bond, Guy L., (1979), Reading Difficulties: Their Diagnosis and Correction, New Jersey : Prentice Hall.

Borg, W.R., Gall, M.D. 2003. Educational Reseach: An Introduction. London: Longman, Inc.

Broto, A.S., (1975), “Membaca”, Jakarta :BinaBahasa, Tahun 2 No. 2

Budiyanto, 2005. PengantarPendidikanInklusifBerbasisBudayaLokal. Jakarta Depdiknas.

Ellison, P.A.T. (2009). The Neuropsychology of Women . Springer Science + Bussines Media. LCC.

Guthrie, J.T., Alao, S., Rinehart, J.M. (1996). Engagemant in Reading for Young Adolescents. Journal of Adolescents and Adult Literacy. 40,4.348-446.

Irdamurni, (2017) Reading Study Model for Dyslexia Children Based on Mingle Technique, , journal of ICSAR. Volume 1( 2 ), 109 - 111

Irdamurni, Kasiyati, Zulmiyetri, JohandriTaufan, (2018), The effect of Mingle model to improve reading skill for students with dyslexia in primary school. journal of (2018),ICSAR. Volume 2 (2), 167-170

Lunandi, A.G.1982. Pendidikan Orang dewasasebuahuraianPraktisuntukPembimbing, Penatar, PelatihdanPenyuluhLapangan, Jakarta: Asokadinata.

Mulyasa, E. 2007. Standar Kompetensi dan Sertifikasi Guru. Bandung:PT.Remaja Rosdakarya.

Moleong, Lexy J, 2007. MetodePenelitianKualitatif. Bandung: RemajaRosdakarya

Shaywitz, S.E. \&Shaywitz B.A. (2003). Neurobiological Indices of Dyslexia. Dalam L. Swanson, K. R. Harris \& S. Graham (Eds). Handbook of Learning Disabilities. (pp 514 -531). New York: Guilford Press. In Nelson, A \&

Vellutino,F.R, Fletcher, J.M, Snowling ,M. J, \&\& Scanlon , D, M (2004), specific reading disability(dyslexia) what have we learned in the past four decades? Journal of child Psichology and psichiatry and allied disciplines, 45 (1), 2-40

Wood P, Winston-Salem. Dyslexia and learning disabilities: Persistence of Behavioral and Neuroimaging Deficits. New York. American Academy of Neurology, 1993.

Yusuf, M. 2003. PendidikanbagiAnakdenganProblemaBelajar. Solo: TigaSerangkaiPustakaMandiri. 